\title{
Effects of reciprocal hybridization on cadmium accumulation in F1 hybrids of Solanum diphyllum and Solanum nigrum
}

\author{
Renyan $\operatorname{Liao}^{1 *}$, LingYu Ma ${ }^{1}$ \\ ${ }^{1}$ Ya'an Polytechnic College, Ya'an, Sichuan 625000, China
}

\begin{abstract}
A pot experiment was conducted to study the effects of reciprocal hybridization on cadmium (Cd) accumulation in F1 hybrid of Solanum diphyllum and Solanum nigrum by $\mathrm{Cd}$ treatment (the final soil $\mathrm{Cd}$ concentration was $10 \mathrm{mg} / \mathrm{kg}$ ). The results showed that the Cd content of F1 hybrid was between the parents. In stems, leaves and shoots, the Cd content of DN (S. diphyllum male $\times S$. nigrum female) and ND (S. nigrum male $\times$ S. diphyllum female) F1 hybrid increased by $14.09 \%$ and $17.34 \%, 8.08 \%$ and $11.14 \%, 9.5 \%$ and $12.04 \%$ respectively compared with $S$. nigrum, and decreased by $13.34 \%$ and $10.87 \%, 6.52 \%$ and $3.88 \%, 7.44 \%$ and $5.0 \%$ respectively compared with $S$. diphyllum, with no significant difference in roots. Therefore, the accumulation ability of $\mathrm{Cd}$ in $\mathrm{F} 1$ hybrids was improved to a certain extent compared to $S$. nigrum, but decreased to a certain extent compared to $S$. diphyllum.
\end{abstract}

\section{Introduction}

With the development of industry, environmental problems come one after another. Heavy metal pollution in soil threatens human's health and life, so it is urgent to solve this problem. Cadmium is one of the heavy metal elements, and excessively high concentration of $\mathrm{Cd}$ will affect redox balance, nutrient absorption, reproductive growth and other aspects of plants [1]. In the first national soil pollution survey in China, it was found that by 2014 , Cd was one of the main pollutants in cultivated land, forest land, grassland and unused land [2]. Zheng et al. [3] investigated in rural areas of Shaanxi Province in 2015 and found that $\mathrm{Cd}$ pollution in the province was serious. $\mathrm{Li}$ [4] found that the Cd content in the road green belt in the south of Shenyang was relatively high. Deng et al. [5] found that Cd content in different types of soil in Guangxi Zhuang Autonomous Region was higher than the standard. All kinds of facts indicated the seriousness of soil $\mathrm{Cd}$ pollution. Therefore, how to solve the problem of Cd pollution in a green and effective way is the top priority.

Solanum nigrum, a one-year to perennial wild herb of the nightshade family, is mostly grown on the roadside or in the fields. It can not only be used for the remediation of Cd-polluted soil, but also is a traditional Chinese herbal medicine in China, which has great development value [67]. Solanine is rich in $S$. nigrum, which is widely used in the treatment of tumors due to its cytotoxicity [8-9]. Studies by Huang et al. [10] have found that solanine has the effect of inhibiting the proliferation of SGC-7901 cells and promoting cell apoptosis in gastric cancer. In addition, the fruit has certain edible value, can be made into drinks, canned, fruit wine, etc [11].

Solanum diphyllum is a variety of $S$. nigrum, mainly distributed in Taiwan. It is a small evergreen shrub with bright fruit, which has certain ornamental value [12]. Besides that, it is found that $S$. diphyllum has certain medicinal value. Guo et al. [13] studied the antioxidant and anti-inflammatory activities in vitro of the fruit extract of $S$. diphyllum, providing a basis for the development of natural antioxidants and anti-inflammatory agents.

To study the influence of interbreeding on $\mathrm{F} 1 \mathrm{Cd}$ accumulation in progeny with $S$. diphyllum and $S$. nigrum as parents plays an important role in increasing species that can be used in phytoremediation technology, which is conducive to the treatment of Cd pollution. In addition, the utilization of the medicinal value of F1 hybrids has positive significance for the treatment of diseases, but the changes of its medicinal properties need to be further studied.

\section{Materials and method}

\subsection{Plant and soil}

The mature seeds of $S$. diphyllum and $S$. nigrum plants were collected from the farmland around the Yucheng District, Ya'an City, Sichuan Province, China in 2018, then the seeds were air-dried and stored at $4{ }^{\circ} \mathrm{C}$. The soil used in the experiment was a fluvo-aquic soil.

\subsection{Hybridizing treatment}

In April 2019, the mature seeds of $S$. diphyllum and $S$. nigrum were sown in the hole tray to be germinated, then transplanted to clean soil when they were about $5 \mathrm{~cm}$ high and with two fully expanded true leaves, and watered irregularly to ensure that soil moisture kept at $80 \%$ field

*Corresponding author. E-mail: 51699474@qq.com 
capacity. The hybridizing treatments were $S$. diphyllum male $\times S$. nigrum female (henceforth $\mathrm{DN}$ ) and $S$. nigrum male $\times S$. diphyllum female (henceforth ND). The hybridizing experiment was carried out as follow: The day before plant flowering, the tweezers was used to poke the female petals and remove and clean the anthers, then the female inflorescences were placed into plastic bags for isolation. Within 1-3 days after castration, at the noon, we opened the bags again, and applied a small amount of male pollens onto the female stigma evenly, and then the female inflorescences were placed into plastic bags for isolation again. About a week after hybridization, when the petals tended to fade and the young fruit formed, we removed the bags and marked it. Subsequently, we collected the matured seeds, air-dried, and stored them separately at $4^{\circ} \mathrm{C}$. Apart from that, the F1 generation of $S$. nigrum seeds was marked as $S$. nigrum, and F1 generation of $S$. diphyllum seeds was $S$. diphyllum.

\subsection{Seedling}

In June 2019, The F1 seeds of S. nigrum, S. diphyllum, DN and ND were sown in uncontaminated potting soil, which was put in a $15 \mathrm{~cm} \times 18 \mathrm{~cm}$ (height $\times$ diameter) plastic basin. Each pot had $3 \mathrm{~kg}$ of soil and with 30 seeds in it. These seeds were covered with $2 \mathrm{~mm}$ soil, and the soil moisture content was kept at $80 \%$ of the field capacity. Then these seedlings were transplanted when they were about $10 \mathrm{~cm}$ high.

\subsection{Cd treatment}

In June to September 2019, the Cd treatment experiment was conducted. There were four treatments: $S$. nigrum, $S$. diphyllum, DN and ND, each treatment was repeated three times, but before that, the uncontaminated soil would be air dried, ground, and sieved with $5 \mathrm{~mm}$ sieves. $3 \mathrm{~kg}$ soil was put in a $15 \mathrm{~cm} \times 18 \mathrm{~cm}$ (height $\times$ diameter) plastic basin, mixed with $\mathrm{CdCl}_{2} \cdot 2.5 \mathrm{H}_{2} \mathrm{O}$ saturated solution until the final soil $\mathrm{Cd}$ concentration was $10 \mathrm{mg} / \mathrm{kg}$, and then incubated for 4 weeks. Soil moisture was kept at $80 \%$ of field capacity. In July 2019, seedlings growing neatly of various F1 were selected and transplanted to the plastic basin with $\mathrm{Cd}$ contaminated soil, and each plastic basin had 4 seedlings. All the plants were placed in transparent awnings, and irregularly watered to keep soil moisture was at $60 \%$ field capacity. The plants would be harvested when they were in full-bloom stage.

\subsection{Biomass and $\mathrm{Cd}$ content determination}

In August 2019, isolating the roots, stems and leaves of all plants, and washing them with tap water and deionized water separately. The single organ would be air dried at $110^{\circ} \mathrm{C}$ for $15 \mathrm{~min}$, then at $75^{\circ} \mathrm{C}$ to a constant weight. Subsequently, the biomass of each dried organ was measured, then, they were finely grounded, digested in $\mathrm{HNO}_{3} / \mathrm{HClO}_{4}(4: 1, \mathrm{v} / \mathrm{v})$, and determined the $\mathrm{Cd}$ contents with iCAP 6300 ICP spectrometer. The Cd extraction by plant was calculated as follows: $\mathrm{Cd}$ extraction= biomass $\times$ Cd content.

\subsection{Statistical analyses}

Statistical analyses were conducted using SPSS 20.0 (IBM, Chicago, IL, USA). Data were subjected to one-way analysis of variance, followed by least significant difference test ( $5 \%$ confidence level).

\section{Results and discussion}

\subsection{Cd content in plants}

The Cd contents in roots of $S$. nigrum were significantly $(p<0.05)$ higher, but in stems, leaves, and shoots of which were significantly $(p<0.05)$ lower than that of $S$. diphyllum. Both the DN and ND F1 hybrids showed a significant increase of $\mathrm{Cd}$ content in different organs except for roots compared with $S$. nigrum parent $(p<0.05)$, while a decrease in that relative to $S$. diphyllum parent (Table 1). The DN F1 hybrid increased Cd content in stems, leaves, and shoots by $14.09 \%(p<0.05), 8.08 \%(p<0.05)$, and $9.5 \%(p<0.05)$ relative to $S$. nigrum parent, but decreased that in these organs by $13.34 \%(p<0.05), 6.52 \%$ $(p<0.05)$, and $7.44 \%(p<0.05)$ relative to $S$. diphyllum parent. While the ND F1 hybrid exhibited an increase of $\mathrm{Cd}$ content in stems, leaves, and shoots by $17.34 \%(p<$ $0.05), 11.14 \%(p<0.05)$, and $12.04 \%(p<0.05)$ relative to $S$. nigrum parent, but a decrease by $10.87 \%(p<0.05)$, $3.88 \%(p>0.05)$, and $5.0 \%(p>0.05)$ relative to $S$. diphyllum parent. Cd content in roots of DN and ND F1 hybrids showed no significant difference between each other, and also with $S$. nigrum parent.

Table 1. Cd content in plants.

\begin{tabular}{ccccc}
\hline Treatments & $\begin{array}{c}\text { Roots } \\
(\mathrm{mg} / \mathrm{kg})\end{array}$ & $\begin{array}{c}\text { Stems } \\
(\mathrm{mg} / \mathrm{kg})\end{array}$ & $\begin{array}{c}\text { Leaves } \\
(\mathrm{mg} / \mathrm{kg})\end{array}$ & $\begin{array}{c}\text { Shoots } \\
(\mathrm{mg} / \mathrm{kg})\end{array}$ \\
\hline S. nigrum & $38.73 \pm 0.92 \mathrm{a}$ & $27.33 \pm 1.38 \mathrm{c}$ & $50.38 \pm 0.87 \mathrm{c}$ & $42.94 \pm 1.09 \mathrm{c}$ \\
S. diphyllum & $34.85 \pm 0.98 \mathrm{~b}$ & $35.98 \pm 1.37 \mathrm{a}$ & $58.25 \pm 1.09 \mathrm{a}$ & $50.64 \pm 1.20 \mathrm{a}$ \\
DN & $37.02 \pm 0.83 \mathrm{ab}$ & $31.18 \pm 0.84 \mathrm{~b}$ & $54.45 \pm 0.48 \mathrm{~b}$ & $46.87 \pm 0.52 \mathrm{~b}$ \\
ND & $38.05 \pm 1.17 \mathrm{a}$ & $32.07 \pm 0.37 \mathrm{~b}$ & $55.99 \pm 1.32 \mathrm{ab}$ & $48.11 \pm 0.89 \mathrm{ab}$ \\
\hline
\end{tabular}

Values are means $( \pm \mathrm{SE})$ of three replicate pots. Different lowercase letters within a column indicate significant differences based on one-way analysis of variance followed by the least significant differences at the $5 \%$ confidence level. 


\subsection{Cd extraction amount of plants}

In the Cd-contaminated soil, the $\mathrm{Cd}$ extraction of $S$. diphyllum was significantly higher in stems, leaves and shoots $(p<0.05)$. Both the DN and ND F1 hybrids showed a significant increase of $\mathrm{Cd}$ extraction in different organs except for roots compared with $S$. nigrum parent $(p<0.05)$, while a decrease in that relative to $S$. diphyllum parent. No significant difference of $\mathrm{Cd}$ extraction by roots existed between all the tested treated samples $(p>0.05)$ (Table 2). The Cd extraction by stems, leaves, shoots of DN and ND F1 hybrids increased by $20.82 \%$ and $28.32 \%(p<0.05)$, $12.70 \%$ and $17.94 \%(p<0.05), 14.38 \%(p>0.05)$ and $20.08 \%(p<0.05)$, respectively, compared to $S$. nigrum parent, but decreased by $23.27 \%$ and $18.51 \%(p<0.05)$, $11.11 \%(p<0.05)$ and $17.94 \%(p>0.05), 14.07 \%(p<$ $0.05)$ and $9.78 \%(p>0.05)$, respectively, relative to $S$. diphyllum parent. The Cd extraction by roots of DN F1 hybrid decreased by $3.03 \%$ and $6.21 \%(p>0.05)$, respectively, compared to $S$. nigrum and $S$. diphyllum, and ND F1 hybrid increased by $9.03 \%(p>0.05)$ and $5.46 \%$
( $p>0.05)$, respectively, compared to $S$. nigrum and $S$. diphyllum.

\section{Conclusions}

To sum up, the Cd content and Cd extraction of DN and ND F1 hybrids were between the two parents after reciprocal hybridization with $S$. diphyllum and $S$. nigrum as parents. Different organs showed different performance. Compared with $S$. nigrum, reciprocal hybridization significantly increased the $\mathrm{Cd}$ content and $\mathrm{Cd}$ extraction in stems, leaves and shoots, while compared with $S$. diphyllum, the $\mathrm{Cd}$ content and $\mathrm{Cd}$ extraction significantly decreased. In roots, there was no significant difference between the F1 hybrids and the parents. Therefore, under the stress of $\mathrm{Cd}$, the $\mathrm{Cd}$ accumulation ability of the F1 hybrid was between $S$. nigrum and $S$. diphyllum. It was improved to a certain extent compared to $S$. nigrum, but decreased to a certain extent compared to $S$. diphyllum. F1 hybrids play active roles in the restoration of $\mathrm{Cd}$-polluted soil.

Table 2. Cd extraction amount of plants.

\begin{tabular}{ccccc}
\hline Treatments & $\begin{array}{c}\text { Roots } \\
(\mu \mathrm{g} / \text { plant })\end{array}$ & $\begin{array}{c}\text { Stems } \\
(\mu \mathrm{g} / \mathrm{plant})\end{array}$ & $\begin{array}{c}\text { Leaves } \\
(\mu \mathrm{g} / \mathrm{plant})\end{array}$ & $\begin{array}{c}\text { Shoots } \\
(\mu \mathrm{g} / \mathrm{plant})\end{array}$ \\
\hline S. nigrum & $36.32 \pm 1.99 \mathrm{a}$ & $24.01 \pm 1.60 \mathrm{c}$ & $92.92 \pm 4.17 \mathrm{c}$ & $116.92 \pm 5.77 \mathrm{c}$ \\
S. diphyllum & $37.55 \pm 3.25 \mathrm{a}$ & $37.81 \pm 2.18 \mathrm{a}$ & $117.81 \pm 4.84 \mathrm{a}$ & $155.62 \pm 7.02 \mathrm{a}$ \\
DN & $35.22 \pm 1.58 \mathrm{a}$ & $29.01 \pm 1.67 \mathrm{~b}$ & $104.72 \pm 2.47 \mathrm{~b}$ & $133.73 \pm 4.13 \mathrm{~b}$ \\
ND & $39.60 \pm 0.85 \mathrm{a}$ & $30.81 \pm 1.33 \mathrm{~b}$ & $109.59 \pm 3.61 \mathrm{ab}$ & $140.40 \pm 4.93 \mathrm{ab}$ \\
\hline
\end{tabular}

Values are means $( \pm$ SE) of three replicate pots. Different lowercase letters within a column indicate significant differences based on one-way analysis of variance followed by the least significant differences at the $5 \%$ confidence level.

\section{References}

1. Xu, J.H., Wang, M., Zhang, R., Wu, L.L. (2020) Research progress on biotoxicity of soil cadmium pollution. Asian Journal of Ecotoxicology, 1-12.

2. The Ministry of Environmental Protection, Ministry of Land and Resources of the People's Republic of China. (2014) Bulletin of the national survey of soil pollution. National Land \& Resources Information, 26-29.

3. Zheng, J.L., Meng, Z.W., Lei, P.Y., et al. (2019) Investigation of lead and cadmium content in rural soil of Shaanxi Province in 2015. Journal of Environment and Health, 36:169-170.

4. Li, Y. (2018) Investigation and analysis of soil pollution in road green belt of Shenyang City. Liaoning Urban and Rural Environmental Science \& Technology, 38: 39-41.

5. Deng, Q.Y., Zhao, Y.J., Lin, Q. et al. (2019) Regional distribution characterstics of cadmium and evaluation of soil pollution situation in Guangxi. Environmental Engineering, 37: 164-171.
6. Song, W.J., Gu, W. (2018) Research progress in pharmacology of Solanum nigrum L. World Science and Technology-Modernization of Traditional Chinese Medicine, 20: 304-308.

7. Xu, T.T., Liu, Y.H., Yang, S.C., et al. (2019) Research progress in the development and utilization of Solanum nigrum. Nongcun Shiyong Jishu, 21-22.

8. Han, Y.L. (2019) Solanine. China Venture Capital, 233.

9. Wu, F.X., Zhao, N., Mei, Q.X., et al. (2017) Antitumor mechanism and research progress of Solanum nigrum. Journal of Chinese Medicinal Materials, 40: 1238-1241.

10. Huang, M.M., Liu, M.Y., Li, B.H., et al. (2020) Solanine regulates proliferation and apoptosis of gastric cancer cells by targeting miR-140/MACC1 pathway. The Chinese Journal of Clinical Pharmacology, 36: 2440-2443.

11. Wang, Q.P., Shen, W., Zhang, K., et al. (2019) Hypochaeris albiflora and Solanum diphyllum, two newly naturalized plants in mainland China. Guihaia, 39: 1724-1728. 
12. Guo, R., Li, Y., W, P. (2020) Evaluation on antioxidant and anti-inflammation in vitro of extracts of three Solanum nigrum L. Berries. Modern Food Science \& Technology, 36: 94-101. 